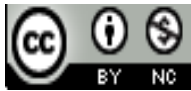 \\ Jurnal Terapan Manajemen dan Bisnis is licensed under \\ A Creative Commons Attribution-NonCommercial 4.0 International License.
}

\title{
E-COMMERCE IN SMALL AND MEDIUM ENTERPRISES (SMES) IN ORDER TO IMPROVE PERFORMANCE
}

\author{
Andi Hendrawan ${ }^{1,2), *}$, Hari Sucahyowati'2), Kristian Cahyandi' ${ }^{2)}$
}

1) Management Science of Soedirman University, Purwokerto, Indonesia

2) Maritime Academy Nusantara, Cilacap, Indonesia

*)E-mail: andi_hendrawan@amn.ac.id

\begin{abstract}
The role of SMEs in the economy of a country, including Indonesia, cannot be underestimated. For example, in the Netherlands, SMEs constitute $98.8 \%$ of existing companies and absorb 55\% of the workforce. A total of 35 million US dollars of Italian exports is the contribution of SMEs that absorb 2.2 million workers. In Vietnam, $64 \%$ of the workforce is absorbed by SMEs. The same thing happened in Indonesia. One application of ICT and the internet in the field of business and trade is electronic commerce (e-commerce). The purpose of the study was to determine the effect of e-commerce on improving the performance of SMEs. Sample to be studied is Small Business Medium in Cilacap, Indonesia. This study uses quota sampling that will be taken a sample of 30 units of SMEs. The sampling technique used is purposive sampling Analyzed performance difference is the performance of SMEs in the show with two dimensions of the increasing number of sales and number of relations, Analysis using statistical program package. Based on the results of the research can be concluded that e-commerce has a positive effect on performance SMEs. This is shown by the increasing sales and relationships of SMEs. More sales will increase the income that the end is the welfare of SMEs.
\end{abstract}

Keywords: Performance; SMEs; E-commerce

\section{Introduction}

Research on e-commerce related to SMEs has been done by many people(Daniel \& Daniel, 2006; Elia, Boeck, \& Lefebvre, 2005; Huy, Rowe, \& Truex, 2012; Olatokun \& Kebonye, 2010; Rashid, Campus, \& Zealand, 2001; Sergis, Zervas, \& Sampson, 2014; Solaymani \& Sohaili, 2012). Small and Medium Enterprises (SMEs) are an important part of the economy of one country or region, as well as in Indonesia. SMEs have a very important role for the nation's economy because of its strategic role in the achievement of national goals, such as economic growth, poverty reduction, economic democratization, job creation, strengthening of industrial base, strengthening local economic structure, balance between sectors and subsectors, as well as a series of social and political goals in nation developmental (Sari \& Hanoum, 2012; Licker, 2001; Olatokun \& Kebonye, 2010).

The role of SMEs in the economy of a country, including Indonesia, cannot be underestimated. For example, in the Netherlands, SMEs constitute $98.8 \%$ of existing companies and absorb 55\% of the workforce. A total of 35 million US dollars of Italian exports 
is the contribution of SMEs that absorb 2.2 million workers. In Vietnam, 64\% of the workforce is absorbed by SMEs. The same thing happened in Indonesia. According to data from the Central Bureau of Statistics and the Ministry of Cooperatives and SMEs in 2005, the number of SMEs in Indonesia reached 43.22 million. The SME sector in Indonesia has proven to have absorbed 79.6 million workers, contributing to $19.94 \%$ export value and $55.67 \%$ of Gross Domestic Product (GDP) (Roosdhani, Wibowo, \& Widiastuti, 2012). In the current era of globalization, the SME sector is required to be able to compete in marketing their business. The empowerment of small and medium enterprises (SMEs) becomes very strategic, because of its great potential in mobilizing the economic activities of the community, and at the same time become the source of income of most people in improving their welfare. SMEs are required to make changes in order to improve their competitiveness. One way to be able to compete in the tight competition of this globalization era is by utilizing information technology in the form of an increasingly growing Internet media.

Small Medium Enterprises (SMEs) in Indonesia seems to have been aware of the presence of B2B marketplaces and their advantages. By surveying members of global B2B marketplace websites, it is found that thousands of Indonesian SMEs have been joining and participating in B2B marketplace websites. In a marketplace website, the Indonesian SMEs even outnumber Chinese SMEs. However, by evaluating the SMEs company profiles, products posted, websites and the export statistics of 2009 provided by World Trade Organization, it is doubtful that Indonesian SMEs have been successful in using global B2B marketplace e-commerce to market their products abroad although e-commerce is reported as useful for enterprises in Indonesia. This fact leads to the research questions: What are the problems faced by Indonesia SMEs in going to global B2B e-commerce via marketplace? What recommendations can be formulated for SMEs development? (Moertini, 2012).

One application of ICT and the internet in the field of business and trade is electronic commerce (e-commerce). E-commerce can be defined as the application and application of e-business (e-business) related to commercial transactions, such as: electronic funds transfer, SCM (supply chain management), e-marketing (e-marketing), or online marketing online marketing, online transaction processing, electronic data interchange (EDI), product promotion and others (Jauhari, 2010). The purpose of the study was to determine the effect of e-commerce on improving the performance of SMEs.

\section{Literature Review}

\section{a. Small and Medium Enterprises (SMEs)}

Small and Medium Enterprises (SMEs) is a form of business seen from the scale of household enterprises and small businesses only have a number of employees between 1-19 people. While medium enterprises have employees of 20-99 people. This SME has proven to be one form of business that can survive in an economic crisis that has occurred in Indonesia (Jauhari, 2010).

Information technology especially internet technology today is very much utilized in various areas of life. Internet technology can facilitate online trading without a meeting between the seller and the buyer. Internet media is currently used as a marketing medium in product sales such as blogs, social media, websites, and E-commerce. E-commerce is a technology that supports online trading transactions. The form of E-commerce is a website with buyer facilities can directly conduct transactions through the website(Suharsana, Wirawan, \& Yuniastari S., 2016).

The basic problems faced by SMEs by (Ariani \& Utomo, 2017)are:

a. Weakness in gaining market opportunities and enlarging market share. 
b. Weakness in capital structure and limitations to obtain a path to capital sources.

c. Weaknesses in the field of organization and human resource management.

d. Limitations of cooperative business networks among small entrepreneurs (marketing information systems).

e. The business climate is less conducive because the competition is mutually deadly.

f. Coaching that has been done is still less integrated and lack of trust as well.

Some major technological capabilities information includes (Eva, 2007):

a. Perform fast numerical computation and large volume capacity.

b. Produce fast, accurate, and inexpensive communication within and between organizations.

c. Large storage capacity in smaller and more accessible media.

d. Allows quick access to information and cheap, global scope.

e. Improve the effectiveness of team/group performance that is spread/different location.

f. Business process automation.

g. Typing and editing density.

h. Abilities are done cheaply compared to the manual way.

With these capabilities, technology information provides important support in business activities, including:

a. Increase productivity

b. Reduce costs

c. Improving the quality of decision making.

d. Increase relationships with customers

e. Consumer Build new strategy apps.

\section{b. E-Commerce}

E-Commerce (electronic commerce) is part of electronic business (business conducted by using electronic transmission). A global definition of e-Commerce is any form of trade in goods or services made electronically. A formal definition of e-Commerce is provided by Baum (2000), which is: a dynamic set of technologies, applications and business processes that connect corporations, consumers, and communities through electronic transactions and trade in goods, services, and information electronically.

Understanding Electronic Commerce (E-Commerce) is the purchase transaction process and product sales, either in the form of services or information that is done electronically using computer communications and one of the networks used is internet or website based. The World Trade Organization (WTO) also provides exposure to E-commerce is the production, advertising, buying and selling, transfer of products/services through an unlimited set of telecommunications online. The Microsoft Corporation Company that defines E-commerce as an exchange of goods or services that has value using Internet technology (Licker, 2001; Olatokun \& Kebonye, 2010).

The use of technology on special purposes such as the creation of e-commerce with the intention of expanding the marketing area that can reach the target market (consumers) to the maximum will generate great benefits for every SME. Theoretically, use is the result of increasing attention (Dima Nuary, 2010) E-commerce enables sellers to market their products quickly, easily and free. By uploading photos and describing products that are supported with recent ad updates, availability of contact links and the availability of quality control over advertisements for the supply of goods and services, free advertising for users and coverage of ad areas throughout Indonesia as well as many others. 
The classification of e-commerce that people usually do is based on the nature of the transaction. The following types can be immediately distinguished:

1. Business to business (B2B), is an e-commerce model where the business is a company, so the transaction and interaction process is between one company with another company. Examples of this e-commerce model are some e-banking sites that serve inter-company transactions.

2. Business to Consumer (B2C), is an e-commerce model where the business directly involves the seller (e-commerce service provider) with individual buyers or buyers. An example of this e-commerce model is airasia.com.

3. Consumer to Consumer (C2C), is an e-commerce model in which individuals or individuals as sellers interact and transact directly with other individuals as buyers. This type of e-commerce concept is widely used in online auction sites or online auctions. An example of an e-commerce portal applying the $\mathrm{C} 2 \mathrm{C}$ concept is e-bay.com.

4. Consumer to Business (C2B), is an e-commerce model in which individual or individual businesses engage in transactions or interactions with one or more companies. This type of e-commerce is very rare in Indonesia. An example of an e-commerce portal applying this business model is priceline.com.

Benefits of E-commerce Benefits to be gained from e-commerce for organizations :

1. Expanding market place to national and international markets.

2. Reduce the cost of making, processing, distributing, storing and searching information using paper.

3. Allow inventory and overhead reduction by simplifying the supply chain and "pull" type management.

4. Reduce time between capital outlay and acceptance of products and services. 5. Supporting business process reengineering effort (Rachmawati, Manajemen, Bina, Informatika, \& Bsi, 2012).

Advances in information technology have been able to create a global network called the Internet. Utilization of the internet today has also thrived in various aspects of life. Various applications exist developed from 3 (three) basic application categories are:

1. Discovery is an application for information access (browsing and information retrieval/searching).

2. Communication ie e-mail, chat, newsgroups.

3. Collaboration is an application for collaboration between individuals/groups, such as workflow systems, screen sharing, visual teleconferencing (teleconferencing), group decision support systems (GDSS). Utilization (Eva, 2007).

\section{c. Hypothesis}

The positive effect of e-commerce on improving the performance of SMEs.

\section{Research Methods}

\section{a. Sample}

Sample to be studied is Small Business Medium in Cilacap, Indonesia. This study uses quota sampling that will be taken a sample of 30 units of SMEs. The sampling technique used is purposive sampling. 


\section{b. Method of Data Collection}

Method primary data collection used in this research is a Questionnaire The questionnaire is used to obtain data on the e-commerce adoption process, perceptions of benefits and constraints.

\section{c. In-depth interview}

In-depth interview was done to identifying more in depth related to the indicator of the research variables used.

\section{d. Data analysis}

Data analysis using $t$ test-test that is a different test on two samples having two different treatment. Group one of fifteen SMEs using E-commerce and fifteen SMEs do not use E-commerce. The analyzed performance difference is the performance of SMEs in the show with two dimensions of the increasing number of sales and number of relations, Analysis using statistical program package.

\section{Results and Discussion}

Table 1 Paired Samples Test

\section{Paired Differences}

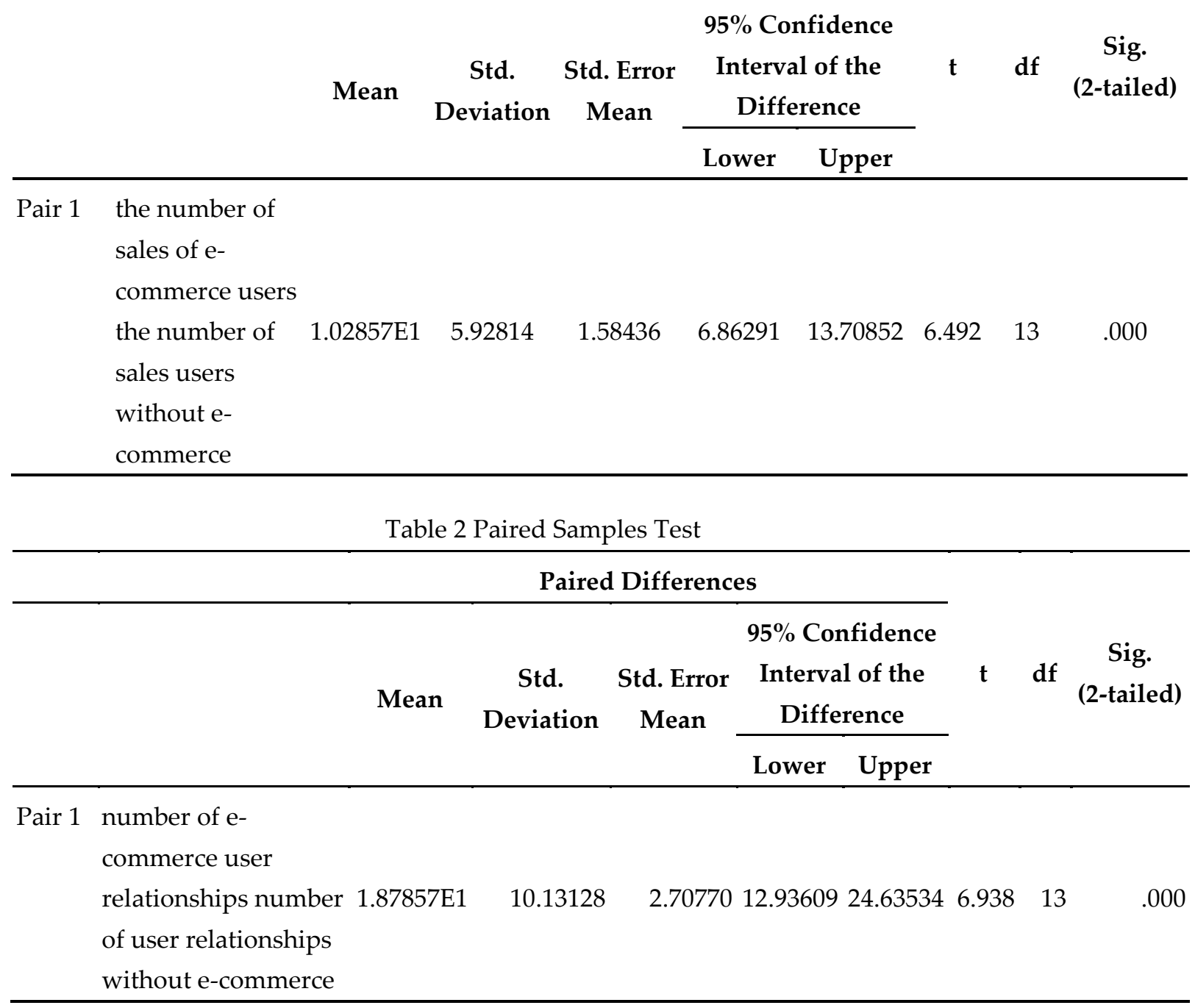


Based on the t-test analysis, there is a significant difference between the number of sales using e-commerce and those who do not use e-commerce. Relationships that use ecommerce and those that do not use e-commerce are also significant with $\mathrm{P}$ values of each $\mathrm{P}=$ 0.00 .

In terms of service (Nindia, Palupi, Santoso, \& Choiri, n.d.) is still not flexible. With the e-commerce website, This is because the customer will do marketing is more flexible. the purchase of silver jewelry products should come at a moment This is because of the ecommerce website outlet open. which is used to connect to the internet that can be accessed 24 hours non-stop, so the customer does not have to wait for the outlet to open a purchase transaction.

In addition, customers can also view products and purchase transactions in cities other than Bali and Yogyakarta. This is because the new system created allows the addition of new outlets outside Bali and Yogyakarta.

Analyses were performed to identify the number of SMEs that use similar business processes to support their operational activities. If there are SMEs which are using the similar process above 50 percent then the process is generally required by SMEs in Indonesia (Handayani, Hidayanto, \& Budi, 2013).

The results of research (Pramudiya, Handarkho, \& Rahayu, 2015) Dolanan Puzzle ECommerce successfully built and able to handle the process of selling, marketing, and ordering goods from Dolanan Puzzle. Implementation of analytical and operational CRM in the form of product recommendations often purchased by other customers when buying an item using the method of Market Basket Analysis, the classification of potential customers used as a target for delivery of new promotional items via e-mail and transaction summary reports from Dolanan Puzzle.

\section{Conclusion}

Based on the results of the research can be concluded that e-commerce has a positive effect on the selling performance SMEs. This is shown by the increasing sales and relationships of SMEs. More sales will increase the income that the end is the welfare of SMEs.

It needs the use of e-commerce in the SME business so that SMEs can grow faster and can compete in the global. Good cooperation is needed across the field to make e-commerce and informatics technologies an important part of the SME business.

Further research on the use of e-commerce in SMEs is required, the use of ICT technology and its role in the development of SMEs.

\section{Reference}

Ariani, \& Utomo, M. N. (2017). Kajian Strategi Pengembangan Usaha Mikro Kecil dan Menengah (UMKM) di Kota Tarakan. Jurnal Organisasi Dan Manajemen, 13(2), 99-118. Retrieved from http://jurnal.ut.ac.id/JOM/article/viewFile/524/575

Daniel, E., \& Daniel, E. (2006). An exploration of the inside-out model : integration in UK SMEs. Journal of Small Business and Enterprise Development, 10(3). https://doi.org/10.1108/14626000310489691

Dima Nuary, F. (2010). IMPLEMENTASI THEORY OF PLANNED BEHAVIOR DALAM ADOPSI E-COMMERCE OLEH UKM (Studi pada UKM yang berada di Kota Surakarta tahun 2009). Retrieved from http://eprints.uns.ac.id/10460/\%5Cnhttp://eprints.uns.ac.id/10460/1/1481916082010103 81.pdf 
Elia, E., Boeck, H., \& Lefebvre, L. (2005). Exploring B-to-B e-commerce adoption trajectories in manufacturing SMEs. L.-A. Lefebvre et Al. / Technovation 25, 25, 1443-1456. https://doi.org/10.1016/j.technovation.2005.06.011

Eva, A. (2007). Persepsi Penggunaan Aplikasi Internet Untuk Pemasaran Produk Usaha Kecil Menengah. Seminar Nasional Aplikasi Teknologi Informasi, 2007(Snati), 1907-5022. https://doi.org/1907-5022

Handayani, P. W., Hidayanto, A. N., \& Budi, I. (2013). Business Process Requirements for Indonesian Small Medium Enterprises (SMEs) in Implementing Enterprise Resource Planning (ERP) and ERP Systems Comparison. Journal of Computers, 8(9), 2437-2441. https://doi.org/10.4304/jcp.8.9.2437-2441

Huy, L. E. Van, Rowe, F., \& Truex, D. (2012). An Empirical Study of Determinants of Ecommerce Adoption in SMEs in Vietnam an economy in transition. Journal of Global Information Management (JGIM), 20(3).

Jauhari, J. (2010). UPAYA PENGEMBANGAN USAHA KECIL DAN MENENGAH (UKM) DENGAN MEMANFAATKAN E-COMMERCE. Jurnal Sistem Informasi (JSI), VOL. 2, NO. 1, April 2010 ISSN Print: 2085-1588 ISSN Online: 2355-4614 Http://ejournal.unsri.ac.id/index.php/jsi/index Halaman, 2(1), 159-168.

Licker, P. S. (2001). E-COMMERCE SYSTEMS SUCCESS : AN ATTEMPT TO EXTEND AND RESPECIFY THE DELONE AND MACLEAN MODEL OF IS SUCCESS. Journal of Electronic Commerce Research, 2(4), 131-141.

Moertini, V. S. (2012). Small Medium Enterprises: On Utilizing Business-to-Business eCommerce to Go Global. Procedia Economics and Finance, 4(Icsmed), 13-22. https://doi.org/10.1016/S2212-5671(12)00316-4

Nindia, I., Palupi, A., Santoso, P. B., \& Choiri, M. (n.d.). ( Studi kasus pada Sentra IKM Perhiasan Perak Tempeh Lumajang ) ENGINEERING OF E-COMMERCE TO SUPPORT DEVELOPMENT MARKETING NETWORK ( Case Studies on Small and Medium-sized Industrial Centers of Silver Jewelry Tempeh Lumajang ). Jurusan Teknik Industri Fakultas Teknik Universitas Brawijaya, 358-368.

Olatokun, W., \& Kebonye, M. (2010). e-Commerce Technology Adoption by SMEs in Botswana e-Commerce Technology Adoption by SMEs in Botswana Introduction. International Journal of Emerging Technologies and Society, 8(1), 42-56.

Pramudiya, H. E., Handarkho, Y. D., \& Rahayu, F. S. (2015). Pengimplementasian CRM Pada Pembangunan E-Commerce untuk Usaha Mikro Kecil Menengah ( Studi Kasus: Dolanan Puzzle ). Buana Informatika, 6(Oktober), 257-268.

Rachmawati, S., Manajemen, A., Bina, K., Informatika, S., \& Bsi, A. (2012). PENGGUNAAN E-COMMERCE PADA UKM UNTUK MENINGKATKAN. CAKRAWALA,VOL XII NO. 2 SEPTEMBER 2012, XII(2), 145-154.

Rashid, M. A., Campus, A., \& Zealand, N. (2001). E-Commerce Technology Adoption Framework by New Zealand Small to Medium Size Enterprises 2 E-commerce in New Zealand. Res. Lett. Inf. Math. Sci.., 63-70.

Roosdhani, M. R., Wibowo, P. A., \& Widiastuti, A. (2012). Informasi Dan Komunikasi Pada Usaha Kecil. 90 JURNAL DINAMIKA EKONOMI \& BISNIS, Vol. 9 No., 89-104.

Sari, R. M., \& Hanoum, S. (2012). Analisis Faktor-faktor yang Mempengaruhi Penggunaan Internet terhadap Peningkatan Kinerja UKM Menggunakan Metode Structural Equation Modelling. Jurnal Teknik ITS, 1, 488-493.

Sergis, S., Zervas, P., \& Sampson, D. G. (2014). ICT COMPETENCE-BASED LEARNING OBJECT RECOMMENDATIONS FOR TEACHERS. 11th International Conference on Cognition and Exploratory Learning in Digital Age (CELDA 2014) Metadata, 150-157. 
Jurnal Terapan Manajemen dan Bisnis

Volume 4 Number 2 September 2018. Page 208-215

e-ISSN: 2477-5282 p-ISSN: 2599-3127

Solaymani, S., \& Sohaili, K. (2012). Adoption and use of e-commerce in SMEs A case study. Electron Commer Res, 249-263. https://doi.org/10.1007/s10660-012-9096-6

Suharsana, I. K., Wirawan, I. W. W., \& Yuniastari S., N. L. A. K. (2016). Implementasi Model View Controller Dengan Framework Codeigniter Pada E-Commerce Penjualan Kerajinan Bali. Jurnal Sistem Dan Informatika, 11(1), 19-28. 